\title{
Hopeful Provocations for a Dialogue with Critical Pedagogy
}

Prof. Shirley R. Steinberg, PhD

University of Calgary, Canada

What the educator does in teaching is make it possible for the students to become themselves.

-Paulo Freire, 1972

\section{Abstract}

In respect for the tentative ways of knowing critical pedagogy, I choose not to define the notion, but rather discuss it from my point of view. It is easier to begin by discussion on what critical pedagogy is not: Critical pedagogy is not prescriptive way of teaching. It is not teacher-proof because it invites teachers to make their own decisions. It is expected to be student-centered but does not prioritize that the student has more to say than the teacher. It is respectful of different traditions, different ways of seeing the world. I would say that critical pedagogy is couched in literacies and, in a non-academic sense, it is couched in the notion of Paulo Freire's notion of reading the world... the word becomes less important than the world, once one understands the world, cultures, societies, people actually do read the word better. For the purpose of this essay, I embed quotes from Freire's work to include his voice within the text.

There's no such thing as neutral education. Education either functions as an instrument to bring about conformity or freedom.

-Richard Shaull, Foreword in Paulo Freire, 1972

Keywords: critical pedagogy; Paulo Freire; power; education.

\section{Introduction}

The term, critical pedagogy, is critical in its orientation as refers to the Frankfurt School of Social Theory established in Germany during the first quarter of the $20^{\text {th }}$ century. A group of mostly Jewish philosophers engaged in a way to redefine Marxism to meet the needs of society 75 years after Marx, adding to the strict notions of political economy and socialism, the Frankfurt School evolved. In my short and simplistic nod to the Frankfurt scholars, the work moved from an orthodox revolutionary theory reduced to capitalism and other political systems to understanding the notion of power, how power worked and how to understand how to work when subjected to power, this included the importance of understanding the evolution of society and cultures. Instead of staying within the within the implications of social class, critical theory interrogated how the world worked, and most importantly, how power worked. Indeed, with a critical theoretical lens, one situates how power works, the forces behind power and under 
power. As pedagogues, those engaged in the science, act, philosophy and scholarship of teaching, we use a critical theoretical approach as we live our lives. Just walking around looking at information environments, listening or viewing media, reading a newspaper...we interrogate what is behind the information we see and hear? who/ what is the financial backing? what is political agenda that supported this information? what is the political power that fights against this information? Critical theory and in this case, critical pedagogy, interrogate the nature of power within a societal situation.

\section{Contextualized teaching and inclusiveness in knowledge creation}

I prefer the word pedagogy because teaching is very much set within societal and historical limitations. In primary school research and discourse, teaching is often looked at as a woman's profession, often dismissed. Secondary school conversations often elevate male participation within the schools, but always one seems to be considered "just a teacher." Whereas the word, pedagogy implies an intellectual viewpoint with pedagogically-aware people who appear aware of their universe and of their students. I'm not sure that labels are ever accurate, however, when one is considered as a critical pedagogue, one is associated with those attributes handed down from Freire. Most importantly, critical pedagogy contextualizes. It asks the questions of where - where the socio-economic forces are? what are the forces of politics? what are the forces of environment? what are the historical forces? contextualizing is essential. As a teacher involved in critical pedagogy one must understand that everything from where she or he teaches, to the curriculum developer, to the administrator, to the students, should be understood by understanding power within that school, the writing of the lessons and how people react to it all. Once a teacher becomes aware of critical pedagogical ways of seeing, being and teaching, a very large universe opens up, it is a dialogical universe surrounded by inquiry and questions, unlike traditional teaching which is expected to shrink and be reduced to lesson plans, units and testing... everything the same for every student.

Leaders who do not act dialogically, but insist on imposing their decisions, do not organize the people-they manipulate them. They do not liberate, nor are they liberated: they oppress.

-Paulo Freire, 1972

A dialogic and inclusive teacher invites students to become part of the work of teaching, it is not a top-down model. Instead, students are partners with the educator, the curriculum is applicable to their lives and schoolwork is assigned to students within a contextual way of learning. Beware, this is not an easy pathway to travel for a teacher, indeed, critical pedagogy is difficult for many because it often comes up against the mindless, archaic, dominant culture-based curriculum instituted by politicians and disconnected school boards. Working within critical pedagogy is hard work, it is about respecting the expectations of the school, but authentically working with students to 
meet the skills and knowledges from where they each come from (both literally and figuratively). It becomes a difficult thing for people involved, this - it's not like this is the number - number one thing to do and oh, it's going to be so easy being a teacher, I can pick this up and run with it." I have often seen students immersed in critical pedagogical work and ready to go to the classroom after university. They are engaged and excited, often creating mirror lessons to re-build existing texts to contextualize with their students. They go into their first school with promise and excitement, and they realize that they are not supposed to find multiple ways of seeing the world. They realize that they're not on the same team as their administrator or colleagues...or even the parents.

\section{Schools as enterprises, between efficiency and effectiveness.}

It is important to look at the origin and purpose of public schooling in English speaking countries, an effort by entrepreneurial men to create and sustain obedient and loyal workers. The etymology of schooling stems from the need to assure factory owners that their workers would be best suited to their jobs and dependable. Creating space for children, (mostly males) to attend public schools modeled on Fredrick Taylor's factory model focused on worker and factory efficiency, young ones were groomed to enter factory life after school. There were few altruistic reasons for the public schools, certainly not a plan to empower, enlighten, and inform. The practicality of the schools were modeled like factories, and the shock to most who review the Tayloristic organization management plans realize that most public schools still employ the same methods and viewpoint in creating obedience. Naturally, a critical theoretical read of the origin of schools reminds us that capitalism and corporate needs opened the way for public schools. Within the Taylor model is the notion to maintain order, and imitating that model, punching in for work is reflected in attendance rolls, notification of time through a factory whistle is reflected in school bells.

The more students work at storing the deposits entrusted to them, the less they develop the critical consciousness which would result from their intervention in the world as transformers of that world. The more complete they accept the passive role imposed on them, the more they tend simply to adapt to the world as it is and to the fragmented view of reality deposited in them.

-Paulo Freire, 1972

Along with the mechanistic ways of schooling we see that curriculum is designed with a similar lockstep intent. What is taught is expected to fit all, and if students are unable to work within the dictated curriculum, they will fail. A Darwinian solution is foisted upon many of our students, and those who work within critical pedagogy experience shock and awe as they read the world of public schools. Curriculum is not only generic in many public schools, it is corporatized. Politicians often work to input curricular changes with direct links to publishers and mass curriculum dispensaries. A glaring example would be 
the implementation of a new education mandate by US President George W. Bush: No Child Left Behind. This national school law reduced many courses to the so-called basics of reading \& writing, math, science and some type of social studies, it was predicated upon the notion that all students' performances must be recorded and tested. Along with the implementation of a new curriculum, the corresponding texts were published and distributed by McGraw-Hill Publishing. McGraw-Hill harvested well over 4 billion US dollars during the first two years of the law. McGraw-Hill's connection to President Bush was not publicly acknowledged, and buried was the almost 100-year-old relationship between the Bush and McGraw families. The implementation of the law raked in money from every curricular area, seemingly random new reading/literacy/writing exercises and books were introduced, no connection nor contextuality appeared in the books and lessons and teachers became reduced to clerks administrating an already-defined curriculum to students. Physical education, art, drama, music, philosophy courses were abandoned and the idea of back to the basics became the herald cry throughout American education. Claiming that the texts and lessons were based on scientific facts, school divisions were harassed to purchase the new products, teachers were sidelined and became deliverers of decontextualized, disconnected factoid lessons. While the new curriculum was introduced in the early 2000s, it replicated the repetitive, rote, stupidified lessons of the early public schools. Many schools, especially those in nonwhite areas were forced to use the programs while schools in higher socio-economic districts continued to deliver the arts, electives and cognitively challenging curriculum. Those children and youth in schools with McGraw-Hill curricula and the obsession with running records and testing fell further and further behind, adding to an alreadyexisting racialized and disenfranchised American education. Certainly, there was no room for critical pedagogy in the Bush-introduced failure, and many teachers who began their careers to work to empower and enlighten students through dialogue and critical thinking left teaching, unable to deal with the mechanical and non-critical pedagogy of the $21^{\text {st }}$ Century, others stayed as teachers, adopting a passive acceptance of a mediocre American education. The corporatization of American education declines student choice and teacher intuition and contextualization. The pressure of exams and standards is a constant for all teachers, yet politicians rarely discuss education and success of students in any positive way. American students' graduation rates drop yearly and many teachers are forced to surrender. Without a critical pedagogical read and understanding of the power of corporatism and nepotism, American education continues to plunge.

\section{Teaching and Power}

If you democratize the curriculum, the authoritarian will say you lack seriousness. -Paulo Freire, 2014 
I believe we must be cynical to understand how to observe and criticalize power. Freire makes it clear that it is in the best interest of those in power to make sure our students and teachers are controlled and lack initiative. Indeed, when teachers are unable to work with students for their own empowerment and benefit and create lessons which apply to the students' own lives and needs, those in power will continue to hold that power. As Paulo noted, when we create a democratic, shared curriculum with our student, understanding that they can read the world and then benefit by the word, we are criticized and feared by those in power. We are called hippie teachers, liberal, without discipline, our work is challenged and for those of us in research who use qualitative analysis we are often accused of not being rigorous. Returning to the original thoughts delineating the Frankfurt school, we must be aware of who holds power and what money is funding power, who is dictating to the dictators? Most countries, even those who espouse democratic values rarely invite many teachers or students onto committees to create standards and curricula. It is in the interest of power to keep the committed, the critical away from decision making. Teachers with freedom create fear, they teach students to be free and to create, this adds to fear, it is not in the interest of a government to have empowered and enlightened students and teachers. On one hand, critical pedagogy is an answer to student engagement, but on the other hand it creates students who have to leave school and live in a world which is governed by money and power. How do we handle this? How do we create a democratic way of being in education which is devoid of governmental manipulation and control? As teachers of teachers we attempt to be honest and direct and work with our pre-service teachers to identify the pitfalls of a critical pedagogical way of being and be saavy enough to work around political control of schools.

The teacher is of course an artist, but being an artist does not mean that he or she can make the profile, can shape the students. What the educator does in teaching is to make it possible for the students to become themselves.

-Paulo Freire, 1972

\section{Paulo Freire heritage between mindset and action}

It goes without saying that Paulo Freire influenced me. Reading Pedagogy of the Oppressed in graduate school allowed me to name and identify the holes and failures in my own education. Freire's ability to draw the themes of education, power, oppression and enlightenment set me on my own path to critical pedagogy. I was able to meet and work with Paulo in the 1990s, he was as authentic and present as anyone I have ever met. His laughter, love of people, food and football lingers with me as does his way of discussing radical love and life. Working with Paulo to write his book, Teachers as Cultural Workers: Letters to Those Who Dare Teach, I wrote the "Afterword" to the second edition, I will end with a portion of that piece of writing: 
Paulo never intended his work and ideology to be adopted as some sort of gospel, methodology, taxonomy, or educational quick-fix. His early work was specifically designed to apply to those students and teachers with whom he worked and lived... Paulo never wanted to be all things to all people, and those that take issue with his work should, in three words, not use it. Ironically, he spent many words during the final years of his life apologizing for un-intentioned omissions and politically incorrect earlier work. That was Paulo... humble, never intending to insert himself into a discourse that would hurt or harm anyone (that is, except for those in the dominant culture).

When it came to those in power, Paulo used his words. He taught that without identifying controlling powers and the hegemonic influences upon citizens, we could never attain empowerment or enlightenment. Our duties as those who taught the marginalized and disenfranchised, were to facilitate the understanding of the origins and ideologies of those in power, and how this understanding related to oppression. He was fearless in his defense of those without power; he was fearless in his anger and indignation for power-wielding brokers who inserted themselves into our schools and communities.

Paulo didn't have time for defending himself. He was too busy attempting to make pedagogy possible. Those who have spent time asking why they are not empowered by his work or the discourse of critical pedagogy are those who are not able to understand the depth of the commitment and humility that must accompany it. I don't have much hope for them, although I think Paulo never lost hope (Steinberg, 2005).

It is necessary that the weakness of the powerless is transformed into a force capable of announcing justice. For this to happen, a total denouncement of fatalism is necessary. We are transformative beings and beings for accommodation.

-Paulo Freire, 1972

\section{Bibliography}

1. Freire, P. (2014). Pedagogy of Hope: Reliving Pedagogy of the Oppressed. New York: Bloomsbury Press.

2. Freire, P. (2000). Pedagogy of Freedom: Ethics, Democracy, and Civic Courage.

3. Freire, P. (1970). Pedagogy of the Oppressed. New York: Continuum Books.

4. Horton, M. \& Freire, P. (1990). We Make the Road by Walking: Conversations on Education and Social Change. Philadelphia: Temple University Press.

5. Shaull, R. (1970). "Introduction." In Pedagogy of the Oppressed. Freire, P. New York: Continuum Books.

6. Steinberg, S. (2005). "Afterword." Teachers as Cultural Workers: Letters to Those Who Dare Teach." Boulder, Co: Westview Press. 